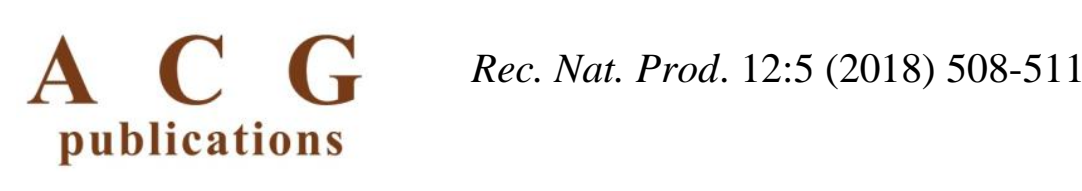

records of natural products

\title{
Composition of Essential Oils from Schefflera myriocarpa Harms (Araliaceae) from Vietnam
}

\author{
Dao T.M. Chau ${ }^{\oplus 1}$, Nguyen H. Hung ${ }^{\oplus 2}$, Le T. Huong ${ }^{\oplus 3, *}$, Nguyen V. Hung ${ }^{\oplus 3}$ \\ and Isiaka A. Ogunwande ${ }^{\odot *}$ \\ ${ }^{1}$ Institute of Biochemical Technology and Environment, Vinh University, 182 Le Duan, Vinh City, \\ Nghệ An Province, Vietnam \\ ${ }^{2}$ Center for Advanced Chemistry, Institute of Research and Development, Duy Tan University, Da \\ Nang City, Vietnam \\ ${ }^{3}$ School of Natural Science Education, Vinh University, 182 Le Duan, Vinh City, Nghệ An Province, \\ Vietnam \\ ${ }^{4}$ Natural Products Research Unit, Department of Chemistry, Faculty of Science, Lagos State \\ University, Badagry Expressway Ojo, P. M. B. 0001, LASU Post Office, Ojo, Lagos, Nigeria
}

(Received November 15, 2017; Revised December 15, 2017; Accepted December 16, 2017)

\begin{abstract}
The aim of this research was to determine the chemical constituents of essential oils derived from the leaf, bark and stems of Schefflera myriocarpa Harms (Araliaceae) grown in Vietnam for the first. The essential oils were obtained by hydrodistillation and investigated through gas chromatography (GC) and gas chromatography-mass spectrometry (GC-MS). The principal compounds identified in the essential oils were mainly monoterpenes represented by $\alpha$-pinene $(17.1 \%-21.2 \%), \alpha$-phellandrene $(9.2 \%-27.4 \%)$ and limonene (19.8\%-36.8\%). In addition, methyl eugenol (10.4\%) was found in the bark.
\end{abstract}

Keywords: Schefflera myriocarpa; essential oil; monoterpenes. (C) 2018 ACG Publications. All rights reserved.

\section{Plant Source}

In the course of phytochemical studies of medicinal plants from Vietnam, we investigated and report herein the chemical compounds identified in the essential oils obtained by hydrodistillation from the leaf, bark and stem of Schefflera myriocarpa Harms (Araliaceae). The mature leaf, bark and stem of S. myriocarpa were collected from Pù Mát National park, Nghệ An Province, Vietnam, in August 2012. Botanical identification was achieved by Dr. Dai. A voucher specimen NDH 265 was deposited at the Botany Museum, Vinh University, Vietnam.

\section{Previous Studies}

The authors are not aware of any information related to the chemical compounds and biological activities of the essential oils of S. myriocarpa from Vietnam or any other parts of the world.

\footnotetext{
* Correspoding authors: E Mail: lehuong223@gmail.com ; isiaka.ogunwande@lasu.edu.ng
} 
Nevertheless, isolation of triterpenes, saponins, caffeoylquinic acid derivatives from Schefflera has been reported [1-4]

Table 1. Chemical constituents of essential oils of S. myriocarpa

\begin{tabular}{|c|c|c|c|c|c|c|}
\hline \multicolumn{7}{|l|}{ Percentage composition $^{\text {a }}$} \\
\hline Compounds ${ }^{b}$ & $\mathbf{R I}^{\mathbf{c}}$ & $\mathbf{R I}^{\mathbf{d}}$ & MI & Leaf & Bark & Stem \\
\hline$\alpha$-Thujene & 931 & 921 & $\mathrm{e}$ & 0.4 & 0.4 & 0.3 \\
\hline$\alpha$-Pinene & 939 & 932 & $\mathrm{f}$ & 17.1 & 21.2 & 15.0 \\
\hline Camphene & 953 & 946 & $\mathrm{e}$ & 0.3 & 0.2 & 0.2 \\
\hline Sabinene & 976 & 964 & $\mathrm{f}$ & - & 2.2 & 1.5 \\
\hline$\beta$-Pinene & 980 & 978 & $\mathrm{e}$ & 5.7 & 2.7 & 2.4 \\
\hline$\beta$-Myrcene & 990 & 988 & $\mathrm{f}$ & 3.6 & 1.5 & 3.1 \\
\hline$\alpha$-Phellandrene & 1006 & 1004 & $\mathrm{f}$ & 25.6 & 9.2 & 27.4 \\
\hline$\alpha$-Terpinene & 1017 & 1014 & $\mathrm{e}$ & 0.6 & 0.7 & - \\
\hline Limonene & 1032 & 1030 & $\mathrm{f}$ & 30.7 & 19.8 & 36.8 \\
\hline (E)- $\beta$-Ocimene & 1052 & 1044 & $\mathrm{f}$ & 0.8 & 4.1 & 1.7 \\
\hline$\gamma$-Terpinene & 1061 & 0156 & $\mathrm{e}$ & 0.1 & 1.1 & 0.1 \\
\hline$\alpha$-Terpinolene & 1090 & 1089 & $\mathrm{e}$ & 0.5 & 0.7 & 1.3 \\
\hline Linalool & 1100 & 1100 & $\mathrm{e}$ & 0.1 & 1.5 & - \\
\hline allo-Ocimene & 1128 & 1128 & $\mathrm{e}$ & 0.1 & 0.1 & 0.1 \\
\hline Terpinene-4-ol & 1177 & 1177 & $\mathrm{e}$ & 0.1 & 2.9 & 0.1 \\
\hline$\alpha$-Terpineol & 1189 & 1187 & $\mathrm{e}$ & - & 0.5 & - \\
\hline Methyl chavicol & 1208 & 1196 & $\mathrm{f}$ & - & 0.1 & - \\
\hline Neral & 1242 & 1249 & $\mathrm{f}$ & - & 0.4 & - \\
\hline Geranial & 1270 & 1273 & $\mathrm{f}$ & - & 0.4 & - \\
\hline Bornyl acetate & 1289 & 1287 & $\mathrm{e}$ & $\mathrm{t}$ & - & 0.1 \\
\hline Bicycloelemene & 1327 & 1337 & $\mathrm{f}$ & 1.3 & - & 0.4 \\
\hline$\alpha$-Cubebene & 1351 & 1345 & $\mathrm{e}$ & 0.1 & 0.9 & 0.9 \\
\hline Eugenol & 1363 & 1373 & $\mathrm{f}$ & 0.1 & 0.7 & 0.1 \\
\hline$\alpha$-Copaene & 1377 & 1374 & $\mathrm{e}$ & 0.1 & 1.3 & 1.2 \\
\hline$\beta$-Bourbonene & 1385 & 1384 & $\mathrm{e}$ & 0.1 & - & - \\
\hline$\beta$-Cubebene & 1388 & 1387 & e & 0.1 & 0.7 & - \\
\hline$\beta$-Elemene & 1391 & 1389 & $\mathrm{e}$ & 0.3 & - & - \\
\hline Methyl eugenol & 1402 & 1402 & $\mathrm{f}$ & 0.3 & 10.4 & 0.3 \\
\hline$\beta$-Caryophyllene & 1419 & 1417 & $\mathrm{e}$ & 2.7 & 4.3 & 1.2 \\
\hline Aromadendrene & 1441 & 1439 & e & $\mathrm{t}$ & - & 0.1 \\
\hline$\alpha$-Humulene & 1454 & 1452 & $\mathrm{e}$ & 1.0 & 0.7 & - \\
\hline Germacrene D & 1485 & 1484 & $\mathrm{e}$ & 0.7 & 0.2 & 0.4 \\
\hline$\alpha$-Amorphene & 1485 & 1485 & $\mathrm{e}$ & 0.2 & - & 0.1 \\
\hline$\beta$-Selinene & 1486 & 1486 & $\mathrm{f}$ & - & 1.4 & - \\
\hline epi-Bicyclosesquiphellandrene & 1489 & 1489 & $\mathrm{f}$ & 0.1 & 0.1 & - \\
\hline Cadine-1,4-diene & 1496 & 1494 & $\mathrm{e}$ & 0.1 & - & - \\
\hline Bicyclogermacrene & 1500 & 1500 & $\mathrm{e}$ & 1.4 & - & 0.5 \\
\hline$\gamma$-Cadinene & 1514 & 1513 & $\mathrm{e}$ & 0.2 & - & - \\
\hline$\delta$-Cadinene & 1525 & 1522 & e & 0.7 & 0.9 & 0.9 \\
\hline Caryophyllene oxide & 1583 & 1581 & $\mathrm{f}$ & 0.1 & - & 0.1 \\
\hline$\tau$-Muurolol & 1646 & 1644 & $\mathrm{e}$ & - & - & 0.2 \\
\hline$\alpha$-Cadinol & 1654 & 1652 & $\mathrm{e}$ & 0.9 & 0.2 & 0.2 \\
\hline Benzyl benzoate & 1760 & 1759 & $\mathrm{f}$ & $\mathrm{t}$ & - & 0.1 \\
\hline 1,2-Benzenedicarboxylic acid & 1917 & 1917 & $\mathrm{f}$ & 0.1 & 0.3 & 0.5 \\
\hline (Z)-9-Octadecanoic acid & 2198 & 2195 & $\mathrm{f}$ & 0.3 & 0.5 & - \\
\hline (Z)-13-Docosenamide & 2625 & 2625 & $\mathrm{f}$ & 1.9 & 3.0 & 0.2 \\
\hline & Total & & 98.5 & 95.3 & 97.5 & \\
\hline Monoter & arbons & & 85.5 & 63.9 & 89.9 & \\
\hline Oxygena & penes & & 0.6 & 16.9 & 0.6 & \\
\hline Sesquite & arbons & & 9.1 & 10.5 & 5.7 & \\
\hline Oxygena & penes & & 1.0 & 0.2 & 0.6 & \\
\hline Non-terp & & & 2.3 & 3.8 & 0.7 & \\
\hline
\end{tabular}

${ }^{\mathrm{a}}$ Standard deviation (SD \pm ) were insignificant and were excluded from the Table; ${ }^{\mathrm{b}}$ Elution order on HP-5MS column; ${ }^{\mathrm{c}}$ Retention indices on HP-5MS column; ${ }^{\mathrm{d}}$ Literature retention indices; ${ }^{\mathrm{e}}$ Identification by mass spectra, GC retention indices and comparison with literature data; ${ }^{\mathrm{f}}$ Identification by mass spectra, GC retention indices, comparison with literature data and co-injection with authentic compounds; MI, mode of identification; - not identified; t, trace amount $(<0.1 \%)$ 
However, the volatile constituents of some other species in the genus have been studied and reported. $\beta$-Caryophyllene (11.1\%-19.2\%), $\alpha$-humulene (7.3\%-15.4\%), germacrene D (3.3\%-14.4\%), germacrene B (8.3\%-21.7\%) and epi- $\alpha$-cadinol (5.6\%-15.0\%) were the major constituents in the oils of the roots, stem and leaf of $S$. stellata from India [5]. The leaf oil of S. rodrigueziana [6] was made up entirely of sesquiterpene hydrocarbons, mostly germacrene D (27.6\%), $\beta$-cubebene $(27.2 \%)$, $\beta$ caryophyllene $(12.2 \%), \alpha$-cubebene $(11.1 \%)$, and $\alpha$-copaene $(10.8 \%)$. The essential oil of $S$. heptaphylla and its major compound (-)- $\beta$-pinene and (+)- $\beta$-pinene showed significant antiproliferative activity against A375 cancer cell lines [7]. The leaf oil of $S$. stellata showed good antifungal activity against Candida albicans and C. glabrata [5] while the leaf oil of S. rodrigueziana displayed notable in-vitro cytotoxicity on MDA-MB-231 cells [6]. Biological results indicated that crude extracts of $S$. vinosa were active against Schistosoma mansoni adult worms [8]. Extracts from $S$. umbellifera have demonstrated potential anti-trypanosoma and anti-plasmodium activities [9].

\section{Present Study}

The essential oils were obtained in yields of $0.21 \%, 0.18 \%$ and $0.30 \%$ (v/w, leaf, bark and stem respectively), calculated on a dry weight basis. The hydrodistillation process afforded light yellow colored essential oils. The main volatile compounds were displayed in Table 1, along with their percentages and retention indices calculated on HP-5MS column. In S. myriocarpa 39, 43 and 32 components representing $98.6 \%, 95.3 \%$ and $97.5 \%$ of the total contents were identified in the leaf, bark and stem oils respectively. The main classes of compounds present in the oils were monoterpene hydrocarbons (63.9\%-89.9\%) and sesquiterpene hydrocarbons $(5.7 \%-10.5 \%)$. The oxygenated monoterpene compounds were present in the bark (16.9\%). The principal compounds identified in the essential oils were mainly monoterpenes represented by $\alpha$-pinene $(17.1 \%-21.2 \%), \alpha$-phellandrene (9.2\%-27.4\%) and limonene (19.8\%-36.8\%). In addition, $\beta$-pinene (5.7\%) was present in the leaf while methyl eugenol (10.4\%), $(E)$ - $\beta$-ocimene $(4.1 \%)$ and $\beta$-caryophyllene $(4.3 \%)$ were the other significant compound in the bark oil.

A comparative analysis of the studied oils of S. myriocarpa with previous data [5-7] indicated that two forms of Schefflera oil samples exist namely: (i) oils dominated by monoterpene hydrocarbons as seen in S. myriocarpa and S. heptaphylla [7]; (ii) oils in which sesquiterpene hydrocarbons predominate observed in S. stellata [5], S. rodrigueziana [6] and S. heptaphylla [10].

In conclusion, for the first time, the compositions of the leaf, bark and stem essential oils of the Vietnamese specie of $S$. myriocarpa were elucidated. Due to the very limited amount of published data on the essential oil of the plants in the genus, comparison of the present results with other studies from Vietnam or other countries was limited.

\section{Supporting Information}

Supporting Information accompanies this paper on http://www.acgpubs.org/RNP

\section{ORCID}

Le Thi Huong: 0000-0003-1123-2037

Nguyen V. Hung:0000-0002-5351-2558

Nguyen H. Hung: $0000-0002-5580-2487$

Dao T. M Chau:0000-0002-0585-2750

Ogunwande Isiaka Isiaka: 0000-0002-5423-887X 


\section{References}

[1] Y. Li, P.P.H. But and V.E.C. Ooi (2005). Antiviral activity and mode of action of caffeoylquinic acids from Schefflera heptaphylla (L.) Frodin, Antiviral Res. 68, 1-9.

[2] Y. Li, R. Jiang, L.S.M. Ooi, P.P.H. But and V.E.C. (2007). Antiviral triterpenoids from the medicinal plant Schefflera heptaphylla, Phytother. Res. 21, 466-470.

[3] R. Liu, Q.Q. Gu, C.B. Cui CB, C. Bing, H.B. Liu, L. Wang and H.S. Guan (2005). 12 $\alpha$,13-Dihydroxyolean-3-oxo-28-oic a new triterpene, and the known oleanonic acid as a new cell cycle inhibitor from Schefflera venulosa, Chin. J. Chem.23, 242-244.

[4] S.H. Tao, F.L. Zeng, Y.F. Chen and Z.B. Shen (2015). Chemical constituents from roots of Schefflera octophylla, Chinese Trad. Herb. Drugs. 21, 134-139.

[5] B. Sabulal, V. George, N.S. Pradeep and M. Dan (2008). Volatile oils from the root, stem and leaves of Schefflera stellata (Gaertn.) Harms (Araliaceae): Chemical characterization and antimicrobial activity, J. Essent. Oil Res. 20, 79-82.

[6] J.D. Richmond, B.R. Agius, B.S. Wright, W.A. Haber, D.M. Moriarity and W.N. Setzer (2009). Essential oil compositions and cytotoxic activities of Dendropanax capillaris, Oreopanax nubigenus, and Schefflera rodrigueziana from Monteverde, Costa Rica, Nat. Prod. Commun. 4, 27-274.

[7] Y.L. Li, C.M. Yeung, L.C.M. Chiu, Y.Z. Cen and V.E.C. Ooi (2009). Chemical composition and antiproliferative activity of essential oil from the leaves of a medicinal herb, Schefflera heptaphylla, Phytother. Res. 23, 140-142.

[8] N. L. Cunha, C.J.U de Mendonça, L.S. Cintra, H.C. de Souza, J.A.Peixoto, C.P. Silva, L.G. Magalhaes, V.M.M. Gimenez, M. Groppo, V. Rodrigues, A.A. da Silva Filho, M.L.A. Silva, W.R.Cunha, P.M. Pauletti and A.H. Januario (2012). In Vitro schistosomicidal activity of some Brazilian Cerrado species and their isolated compounds, Evid. Based Complement. Alternat. Med. 2012, 173614.doi: 10.1155/2012/173614

[9] T.A. Mokoka, S. Zimmermann, T. Julianti, Y. Hata, N. Moodley, M. Cal, M. Adams, M. Kaiser, R. Brun, N. Koorbanally and M. Hamburger (2011). In vitro screening of traditional South African malaria remedies against Trypanosoma brucei, rhodesiense,Trypanosoma cruzi, Leishmania donovani, and Plasmodium falciparum, Planta Med. 77, 1663-1667.

[10] H. Wang, Y.Q.Liu, S.L. and W.Z, Yan (2012). Comparative seasonal variation and chemical composition of essential oils from the leaves and stems of Schefflera heptaphylla using microwave-assisted and conventional hydrodistillation, Ind. Crops Prod. 36, 229-237.

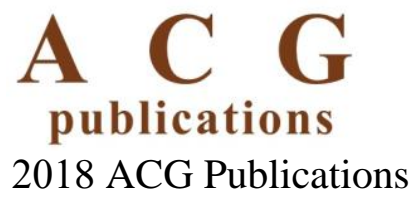

